\title{
Microorganisms Isolated from Wound Samples and Their Antibiotic Resistance Rates
}

öz

Bu çalışmada, hastanemizin mikrobiyoloji laboratuvarına gönderilen yara yeri örneklerinden izole edilen patojen mikroorganizmaların dağılımı ve antibiyotik duyarlııkları belirlenerek, epidemiyolojik verilere katkı sağlanması ve ampirik tedavide yol gösterici olunması amaçlanmıştır.

Laboratuvarımıza 02.01.2017-20.07.2020 tarihleri arasında gönderilen yara yeri enfeksiyonu etkenleri retrospektif olarak incelenmiştir. Üreyen mikroorganizmalar konvansiyonel mikrobiyolojik yöntemler ve otomatize sistem ile tanımlanmıştır. Antibiyotik duyarlılık testleri Kirby-Bauer disk difüzyon yöntemi veya otomatize sistem ile yapılmış ve EUCAST kriterlerine göre değerlendirilmiştir.

Çalışmamızda 722 örnekten izole edilen toplam 956 etkenin 370'i (\% 39) Enterobacterales takımı, 286'sı (\% 30) Gram pozitif kok, 134'ü (\% 14) Pseudomonas spp., 83'ü (\% 9) Acinetobacter baumannii, 27'si (\% 3) Candida spp. olarak tanımlanmıstır. Stafilokok ve enterokoklarda vankomisin, teikoplanin ve linezolid direncine rastlanmamışsır. Staphylocoocus aureus'a karşı en etkili antibiyotiğin trimetoprimsülfametoksazol (TMP-SXT) (\% 11), koagülaz negatif stafilokoklara ise gentamisin (\% 30) ve TMP-SXT (\% 28) olduğu saptanmıştır. Enterokoklarda siprofloksasin (\% 48) ve levofloksasin (\% 58) direncinin diğer antibiyotiklerden yüksek olduğu belirlenmiştir. Ayrıca, Klebsiella spp. suşlarııın diğer Enterobacterales cinsi suşlardan daha yüksek direnç oranlarına sahip olduğu ve A. baumannii ve Pseudomonas spp. suşlarında en düşük direnç oranının kolistine (\% 1) karşı olduğu belirlenmiştir. Yoğun bakım ünitelerinde ise enterokoklar dışındaki etkenlerde antibiyotik direncinin diğer kliniklerden yüksek olduğu saptanmıştır.

Çalıșmamızda birçok bakteri türü ve mantarların yara yeri enfeksiyonunda etken olabildiği ve antibiyotiklere oldukça yüksek oranlarda direnç geliştiği görülmüştür. Bu nedenle tüm yara yeri enfeksiyonu düşünülen örneklere kültür ve antibiyogram işlemlerinin yapılarak tedavilerin düzenlenmesi gerektiği düşünülmüştür.

Anahtar kelimeler: antibiyotik direnci, yara yeri enfeksiyonları, yoğun bakım ünitesi

\section{ABSTRACT}

In this study, it was aimed to contribute to available epidemiological data and guide empirical treatment by determining the distribution and antibiotic susceptibility of pathogenic microorganisms isolated from wound samples sent to the microbiology laboratory of our hospital.

The agents of wound infection sent to our laboratory between 02.01.2017 and 20.07.2020 were retrospectively analyzed. The microorganisms grown were identified by conventional microbiological methods together with automated system. Antibiotic susceptibility testing was done by Kirby-Bauer disk diffusion method and an automated system and evaluated according to EUCAST criteria.

Of the 956 bacteria isolated from 722 samples, 370 (39 \%) were order Enterobacterales, 286 (30\%) were Gram positive cocci, 134 (14\%) were Pseudomonas spp., 83 (9\%) were Acinetobacter baumannii and $27(3 \%)$ were Candida spp. Vancomycin, teicoplanin and linezolid resistance were not found in staphylococci and enterococci. The most effective antibiotic against Staphylococcus aureus was trimethoprim-sulfamethoxazole (TMP-SXT) (11\%), and gentamicin (30 \%) and TMP-SXT (28\%) for coagulase negative staphylococci (CNS). Ciprofloxacin (48\%) and levofloxacin (58\%) resistance was higher in enterococci compared to other antibiotics. In addition, Klebsiella spp. strains have higher resistance rates than other Enterobacterales genus strains while A. baumannii and Pseudomonas spp. strains had the lowest resistance rate against colistin (1\%). Antibiotic resistance was higher in intensive care units than in other clinics, except for enterococci.

In our study, it was observed that many species of bacteria and fungi could be an agent in wound infection, and high rates of resistance developed against antibiotics. Therefore, it was thought that the treatments should be regulated by performing culture and antibiogram procedures on all samples for which wound infection is suspected.

Keywords: antibiotic resistance, intensive care unit, wound infections
Received/Geliș: 23.02.2021

Accepted/Kabul: 08.04.2021

Published Online/Online Yayın: 29.04.2021

Atıf/Cite as: Köse E, Çalışkan E, Memiş $N$, Dönmez B, Duran P. Yara yeri örneklerinden izole edilen mikroorganizmalar ve antibiyotik direnç oranları. ANKEM Derg. 2021;35(1):14-21

Ezgi Köse

Düzce Üniversitesi Tıp Fakültesi, Tıbbi Mikrobiyoloji Anabilim Dalı Düzce - Türkiye ezgii.kosee93@gmail.com ORCID: 0000-0001-5602-0551

E. Çalışkan 0000-0002-9451-7865 N. Memiş 0000-0001-6980-9244

B. Dönmez 0000-0003-1790-7621 P. Duran 0000-0002-7838-2067 Düzce Üniversitesi Tıp Fakültesi, Tıbbi Mikrobiyoloji Anabilim Dalı Düzce - Türkiye 


\section{GiRiş}

Deri, insan vücudu ile dış çevresi arasında koruyucu bir bariyer görevi gören hayati bir organdır. Derideki ülserler veya travmatik yaralar, deri altı dokuyu açığa çıkararak mikrobiyal kolonizasyon için uygun nem, sıcaklık ve besleyici koşullar sağlamaktadır ${ }^{(7,21)}$. Bu yaralar kronik yara olarak tanımlanan, üç ay boyunca boyutunda küçülme olmayan veya artış gösteren ülserler olabileceği gibi üç ay içinde normal iyileşme sürecinden geçen akut yaralar da olabilmektedir ${ }^{(17)}$. Yara yeri enfeksiyonları travma, cerrahi kesi, dekübit ülseri, yabancı cisim gibi ekzojen nedenlerle ya da apse, osteomyelit, septik artrit ve diş enfeksiyonları gibi endojen kaynaklardan oluşabilmektedir ${ }^{(18)}$. Hastane kaynaklı enfeksiyonlarda ilk üç sıraya giren yara yeri enfeksiyonları, oluştuğu takdirde hastayı psikolojik olarak da etkileyebilmekte, hastanede yatış süresini uzatmakta, morbidite ve mortaliteyi arttırabilmektedir(26). Dekübit yara enfeksiyonları gibi kronik yaralarda enfeksiyon çoğunlukla polimikrobiyal olarak gelişmekte, etken olarak ise birçok ajan suçlanmakla birlikte en sık enterik bakteriler, nonfermentatif bakteriler ve Gram pozitif bakteriler saptanmaktadır. Bu enfeksiyonlar; sellülit, osteomyelit ve sepsis gibi daha ciddi ve hayatı tehdit eden durumlara neden olabilmek-

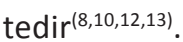

Bakterilerde artan antimikrobiyal direnç ise bütün dünyada olduğu gibi ülkemizde de önemli bir sağlık sorunu olma özelliğini sürdürmektedir ${ }^{(19)}$. Yara enfeksiyonu etkenlerinin antimikrobiyal duyarlılıklarının değerlendirilmesi, klinisyene tedavi başarısında destek olacak ve antimikrobiyallerin bilinçli kullanımını sağlayarak dirençli bakterilerin ortaya çıkmasını ve yayılmasını engelleyecektir. Bu çalışmada da, hastanemizin mikrobiyoloji laboratuvarına gönderilen yara yeri örneklerinden izole edilen patojen mikroorganizmaların dağılımı ve antibiyotik duyarlılıkları belirlenerek ampirik tedavide yol gösterici olunması amaçlanmıştır.

\section{GEREÇ VE YÖNTEM}

Laboratuvarımıza

02.01.2017-20.07.2020 tarihleri arasında gönderilen ve Gram boyaması Q skoruna göre değerlendirilerek enfeksiyon varlığı belirlenen yara yeri kültürleri retrospektif olarak incelenmiştir. Örneklerin ekimi \% 5 koyun kanlı agar ve "eosin methylene blue" agara (EMB) (Oxoid, Ingiltere) yapılarak $35^{\circ} \mathrm{C}$ 'de $18-24$ saat aerobik ortamda inkübe edilmiştir. Üreyen mikroorganizmalar konvansiyonel mikrobiyolojik yöntemler veya otomatize sistem (VITEK 2, bioMérieux, Fransa) ile tanımlanmıştır. Gram pozitif koklar, Enterobacterales takımına ait türler, Pseudomonas spp. ve Acinetobacter baumannii suşlarının antibiyotik duyarlılıkları Kirby-Bauer disk difüzyon yöntemi veya otomatize sistem (VITEK 2, bioMérieux, Fransa) ile çalışılmış ve European Committee on Antimicrobial Susceptibility Testing (EUCAST) kriterlerine göre belirlenmiştir. Kolistin duyarlılığını saptamada SIVı mikrodilüsyon yöntemi uygulanmıştır ${ }^{(22)}$. Verilerin istatistiksel değerlendirmesinde SPSS 22.0 (IBM Corp.) paket programında Ki-kare ve Fisher's Excat, Fisher- Freeman- Halton testleri kullanılmıştır. $p<0,05$ değeri istatistiksel olarak anlamlı kabul edilmiştir. Çalışma için Düzce Üniversitesi Tıp Fakültesi invaziv olmayan klinik araştırmalar etik kurulundan 07.12.2020 tarih ve 2020/253 numarası ile izin alınmıştır.

\section{BULGULAR}

Çalışmaya hastanemizin çeşitli poliklinik, servis ve yoğun bakım ünitelerinden gönderilen 722 hastaya ait yara yeri örneği dahil edilmiştir. Hastaların 337'sinin (\% 47) kadın, 385'inin (\% 53) erkek olduğu ve yaş ortalamalarının $55,7 \pm 22,9$ (en küçük 0- en büyük 99) olduğu görülmüştür. Toplam 772 örnekten izole edilen 956 etkenin 628'i (\% 66) Gram negatif basil, 301'i (\% 31) Gram pozitif kok, 27'si (\% 3) maya olarak saptanmıştır. 370'i (\% 39) Enterobacterales takımına ait türler, 233'ü (\% 23) stafilokok, 53'ü 
enterokok (\% 6), 134'ü (\% 14) Pseudomonas spp., 83'ü (\% 9) A. baumannii, 27'si (\% 3) Candida spp. (16'sı C.albicans, altısı C.glabrata, ikisi C.guilliermondii, ikisi C.tropicalis, biri C.krusei), 15'i (\%2) beta hemolitik streptokok, 11 'i (\% 1) Stenotrophomonas maltophilia, 30'u (\% 3) diğer bakteriler olarak saptanmıştır.

Hastaların 526'sında (\% 73) tek, 196'sında (\% 27) çoklu etken üremesi saptanmıştır. Bir hastada iki veya üç mikroorganizma türü üremesinin, yoğun bakım ünitelerindeki hastalardan gönderilen yara yeri örneklerinde, dahili ve cerrahi bölüm hastalarından gönderilen yara yeri örneklerine göre daha fazla olduğu belirlenmiş̧ir $(p<0,05)$.

Stapylococcus aureus suşlarında gentamisin, siprofloksasin, trimetoprim-sülfametoksazol (TMPSXT), eritromisin, klindamisin, sefoksitin ve fusidik asit direnç oranlarının koagülaz negatif stafilokok (KNS) suşlarından daha düşük olduğu saptanmıştır $(p<0,05)$. Levofloksasin ve tetrasiklin duyalılığının ise KNS ve S.aureus'ta benzer olduğu görülmüştür $(p>0,05)$. Stafilokok suşlarında vankomisin, teikoplanin ve linezolid direncine rastlanmamıştır. Bu antibiyotikler dışında S.aureus'a karşı en etkili antibiyotiğin TMP-SXT, KNS'ye karşı en etkili antibiyotiklerin ise gentamisin ve TMP-SXT oldukları saptanmıştır. Enterokoklarda da vankomisin, teikoplanin ve linezolid direnci görülmemiş; siprofloksasin ve levofloksasin direncinin diğer antibiyotiklerden yüksek olduğu belirlenmiştir. Gram pozitif bakterilerin antibiyotik direnç oranları Tablo 1 'de gösterilmiştir.

Enterobacterales takımına ait türlerin antibiyotik direnç oranları incelendiğinde, Klebsiella spp. suşlarının çalışmaya dahil edilen tüm antibiyotiklere diğer bakterilerden daha yüksek oranda direnç gösterdiği belirlenmiştir $(p<0,05)$. Bakterilerin antibiyotik duyarlılıkları Tablo 2'de gösterilmiştir.

Nonfermenter Gram negatif bakterilerden A.baumannii ve Pseudomonas spp. suşlarının antibiyotik direnç oranları incelendiğinde; imipenem, gentamisin, amikasin ve tobramisin direncinin A.baumannii suşlarında Pseudomonas spp. suşlarından daha fazla oduğu belirlenmiştir. Kolistin direnci her iki bakteri türü için de \% 1 olarak belirlenmiştir. Kolistin haricinde Pseudomonas spp. suşlarının en duyarlı olduğu antibiyotiklerin gentamisin, amikasin ve tobramisin; A.baumannii suşlarının ise en duyarlı olduğu antibiyotiklerin tobramisin ve tigesiklin olduğu saptanmıştır (Tablo 3).

Yoğun bakım ünitesindeki hastalardan gönderilen yara yeri örneklerinden izole edilen bakterilerde kinolonlar başta olmak üzere, bazı antibiyotiklere direncin diğer kliniklerden gönderilen örneklerden

Tablo 1. Gram pozitif bakterilerin antibiyotik direnç oranları $(n=286)$.

\begin{tabular}{|c|c|c|c|c|c|c|}
\hline \multirow{3}{*}{ Antibiyotik } & \multicolumn{6}{|c|}{ Bakteri türü } \\
\hline & \multicolumn{2}{|c|}{ S. aureus $(\mathrm{n}=142)$} & \multicolumn{2}{|c|}{ KNS (n=91) } & \multicolumn{2}{|c|}{ Enterococcus spp. $(n=53)$} \\
\hline & $\mathbf{n}$ & $\%$ & $\mathbf{n}$ & $\%$ & $\mathbf{n}$ & $\%$ \\
\hline Metisilin & $50 / 140$ & 36 & $54 / 89$ & 61 & - & - \\
\hline Gentamisin & $21 / 125$ & 17 & $26 / 86$ & 30 & - & - \\
\hline TMP-SXT & $15 / 137$ & 11 & $25 / 90$ & 28 & - & - \\
\hline Eritromisin & $47 / 140$ & 34 & $55 / 91$ & 60 & - & - \\
\hline Klindamisin & $28 / 139$ & 20 & $42 / 88$ & 48 & - & - \\
\hline Fusidik asit & $2 / 14$ & 14 & $5 / 6$ & 83 & - & - \\
\hline Tetrasiklin & $34 / 140$ & 24 & $32 / 90$ & 36 & - & - \\
\hline Levofloksasin & $28 / 127$ & 22 & $29 / 80$ & 36 & $25 / 43$ & 58 \\
\hline Siprofloksasin & $33 / 140$ & 24 & $34 / 89$ & 38 & $23 / 48$ & 48 \\
\hline Vankomisin & $0 / 141$ & - & $0 / 90$ & - & $0 / 53$ & - \\
\hline Teikoplanin & $0 / 142$ & - & 0/91 & - & $0 / 53$ & - \\
\hline Linezolid & $0 / 141$ & - & $0 / 90$ & - & $0 / 51$ & - \\
\hline Gentamisin YD & - & - & - & - & $15 / 50$ & 30 \\
\hline Streptomisin YD & - & - & - & - & $18 / 49$ & 37 \\
\hline Ampisilin & - & - & - & - & $16 / 51$ & 31 \\
\hline
\end{tabular}

TMP-SXT: Trimetoprim-sülfametoksazol, YD: Yüksek düzey 
Tablo 2. Enterobacterales takımına ait türlerin antibiyotik direnç oranları $(n=370)$.

\begin{tabular}{|c|c|c|c|c|c|c|c|c|c|c|}
\hline \multirow{3}{*}{ Antibiyotik } & \multicolumn{10}{|c|}{ Bakteri türü } \\
\hline & \multicolumn{2}{|c|}{$\begin{array}{l}\text { Escherichia coli } \\
\qquad(n=145)\end{array}$} & \multicolumn{2}{|c|}{$\begin{array}{l}\text { Klebsiella spp. } \\
\quad(n=82)\end{array}$} & \multicolumn{2}{|c|}{$\begin{array}{l}\text { Proteus spp. } \\
\qquad(n=61)\end{array}$} & \multicolumn{2}{|c|}{$\begin{array}{l}\text { Enterobacter spp. } \\
\qquad(\mathrm{n}=50)\end{array}$} & \multicolumn{2}{|c|}{$\begin{array}{l}\text { Diğer* } \\
(n=32)\end{array}$} \\
\hline & $\mathbf{n}$ & $\%$ & n & $\%$ & $\mathbf{n}$ & $\%$ & $\mathbf{n}$ & $\%$ & n & $\%$ \\
\hline Ampisilin & $113 / 133$ & 85 & - & - & $34 / 56$ & 61 & - & - & - & - \\
\hline AMC & $86 / 143$ & 60 & $57 / 79$ & 72 & $26 / 59$ & 44 & - & - & - & - \\
\hline Sefuroksim & $84 / 138$ & 61 & $58 / 78$ & 74 & $16 / 58$ & 28 & $28 / 46$ & 61 & -** & -** \\
\hline Sefotaksim & 77/136 & 57 & $49 / 70$ & 70 & $6 / 57$ & 11 & $14 / 44$ & 32 & $4 / 27$ & 15 \\
\hline Seftriakson & 78/143 & 55 & $54 / 77$ & 70 & $3 / 59$ & 5 & $14 / 46$ & 30 & $2 / 30$ & 7 \\
\hline Seftazidim & 74/138 & 54 & $56 / 80$ & 70 & $6 / 60$ & 10 & $22 / 46$ & 48 & $4 / 32$ & 13 \\
\hline Sefepim & $72 / 143$ & 50 & $54 / 82$ & 66 & $3 / 55$ & 6 & $7 / 48$ & 15 & $1 / 31$ & 3 \\
\hline TMP-SXT & $64 / 134$ & 48 & $48 / 78$ & 62 & $36 / 60$ & 60 & $8 / 47$ & 17 & $8 / 32$ & 25 \\
\hline Gentamisin & 40/139 & 29 & $35 / 75$ & 47 & $20 / 57$ & 19 & $6 / 45$ & 13 & $4 / 32$ & 13 \\
\hline Amikasin & 28/143 & 20 & $25 / 81$ & 31 & $6 / 58$ & 10 & $5 / 49$ & 10 & $2 / 31$ & 7 \\
\hline Tobramisin & $57 / 135$ & 42 & $41 / 71$ & 58 & $18 / 57$ & 32 & $13 / 45$ & 29 & $3 / 28$ & 11 \\
\hline Piperasilin & $102 / 137$ & 75 & $59 / 71$ & 83 & $20 / 56$ & 36 & $16 / 46$ & 35 & $7 / 29$ & 24 \\
\hline TZP & $62 / 140$ & 44 & $48 / 79$ & 61 & $5 / 58$ & 9 & $16 / 48$ & 33 & $2 / 31$ & 7 \\
\hline Siprofloksasin & $70 / 139$ & 50 & $44 / 78$ & 56 & $16 / 58$ & 28 & $9 / 49$ & 18 & $5 / 31$ & 16 \\
\hline Levofloksasin & $63 / 128$ & 49 & $32 / 66$ & 49 & $13 / 53$ & 25 & $6 / 43$ & 14 & $4 / 29$ & 14 \\
\hline İmipenem & $3 / 139$ & 2 & $15 / 73$ & 21 & $2 / 57$ & 4 & $1 / 44$ & 2 & $1 / 28$ & 5 \\
\hline Ertapenem & $22 / 145$ & 15 & $34 / 78$ & 44 & $6 / 60$ & 10 & $11 / 46$ & 24 & $2 / 29$ & 7 \\
\hline Tigesiklin & $15 / 177$ & 13 & $35 / 69$ & 51 & - & - & $14 / 41$ & 34 & $17 / 27$ & 63 \\
\hline
\end{tabular}

AMC: Amoksisilin klavulanik asit, TMP-SXT: Trimetoprim-sülfametoksazol, TZP: Piperasilin-tazobaktam,

*Diğer: Morganella morganii ( $n=15)$, Serratia marcescens $(n=14)$, Citrobacter spp. $(n=3)$, **: Serratia marcescens doğal dirençli olduğundan bu grup verisi tabloya dahil edilmemistir.

Tablo 3. Nonfermenter Gram negatif bakterilerin antibiyotik direnç oranları $(n=217)$.

\begin{tabular}{lcccc}
\hline & \multicolumn{5}{c}{ Bakteri türü } \\
\cline { 2 - 5 } Antibiyotik & $\begin{array}{c}\text { Pseudomonas spp. } \\
\text { (n=134) }\end{array}$ & $\begin{array}{c}\text { Acinetobacter baumannii } \\
\text { (n=83) }\end{array}$ \\
\hline & $\mathbf{n}$ & $\%$ & $\mathbf{n}$ & $\%$ \\
\hline Imipenem & $43 / 132$ & 33 & $72 / 78$ & $\mathbf{9 2}$ \\
Gentamisin & $24 / 128$ & 19 & $67 / 82$ & $\mathbf{8 2}$ \\
Amikasin & $23 / 131$ & 18 & $69 / 82$ & $\mathbf{8 4}$ \\
Tobramisin & $19 / 123$ & 15 & $52 / 71$ & $\mathbf{7 3}$ \\
TZP & $48 / 133$ & 36 & - & - \\
Piperasilin & $58 / 128$ & 45 & - & - \\
Sefepim & $46 / 130$ & 35 & - & - \\
Kolistin & $1 / 97$ & 1 & $1 / 78$ & 1 \\
Tigesiklin & - & - & $53 / 79$ & 67 \\
TMP-SXT & - & - & $61 / 79$ & 77 \\
Seftazidim & $46 / 130$ & 35 & - & - \\
Levofloksasin & $54 / 127$ & 43 & $63 / 67$ & 94 \\
Siprofloksasin & $58 / 130$ & 45 & $75 / 81$ & 93 \\
& & & & \\
\hline
\end{tabular}

TZP: Piperasilin-tazobaktam,

TMP-SXT: Trimetoprim-sülfametoksazol

izole edilen bakterilerdeki dirençten istatistiksel olarak anlamlı şekilde yüksek olduğu saptanmıştır (Tablo 4).

\section{TARTIŞMA}

Mikrobiyolojik açıdan yara örneklerinin
Tablo 4. Yoğun bakım ünitelerinde diğer kliniklere göre ddaha yüksek direnç oranı saptanan antibiyotikler (\%).

\begin{tabular}{lcccc}
\hline Antibiyotik & Enterobacterales & Stafilokoklar & Enterokoklar & NFGNB \\
\hline Siprofloksasin & 67 & 71 & $*$ & 86 \\
Levofloksasin & 66 & 83 & $*$ & 83 \\
Gentamisin & 44 & 71 & - & 54 \\
Amikasin & 34 & - & - & 62 \\
Tobramisin & $*$ & - & & 55 \\
Imipenem & 15 & - & - & 73 \\
Ertapenem & 36 & - & - & - \\
TMP-SXT & 65 & $*$ & - & $*$ \\
Seftriakson & 62 & - & - & - \\
Seftazidim & 64 & - & - & 68 \\
Sefotaksim & 62 & - & - & - \\
Sefepim & 60 & - & - & 65 \\
TZP & 59 & - & - & 76 \\
Piperasilin & $*$ & - & - & 73 \\
\hline
\end{tabular}

TMP-SXT: Trimetoprim-sülfametoksazol, TZP: Piperasilin-tazobaktam, NFGNB: Nonfermenter Gram Negatif Basil

Piperasilin, TZP, seftazidim ve sefepim NFGNB'lerden yalnizca Pseudomonas spp. suşları için, SXT ise A. baumannii suşları için hesaplanmıştır.

-: değerlendirme dışı, *: diğer kliniklerle benzer direnç oranı

incelenmesi, diğer örnek türlerine göre daha zaman alıcıdır ve dikkat gerektirmektedir. Yara enfeksiyonu düşünülen hastalarda, örnekler doğru şekilde alınmaz ise deri florasında bulunan bakteriler etken mikroorganizma olarak izole edilebilirler ${ }^{(16)}$. Bu da uygunsuz antibiyotik kullanımına ve tedavi süresinin uzamasına yol açabilir. Mikrobiyoloji laboratuvarı 
tarafından etkenin doğru tespit edilmesi ve antibakteriyel duyarlılıklarının belirlenmesi, klinisyenin tedavi kararlarında önemli kolaylık sağlamaktadır(15).

Ülkemizde yapılan birçok çalışmada, bizim çalışmamızla benzer şekilde yara yeri enfeksiyonlarında Gram negatif bakterilerin daha sık etken olduğu görülmektedir. Gram negatif bakteri sıklığının \% 53 ile \% 80,2; Gram pozitif bakteri sıklığının ise \% 21,2 ile \% 46,4 arasında olduğu bildirilmektedir ${ }^{(3,4,8,11,14,25)}$. Zdravkovska ve ark.'nın ${ }^{(27)}$ Kuzey Makedonya'da yapmış olduğu bir çalışmada ameliyat sonrası yaralarda en yaygın izole edilen patojenler S.aureus (\% 27), Escherichia coli (\% 17) ve P.aeruginosa (\% 13) olarak belirlenmiştir. Abdu ve ark. ${ }^{(1)}$ Nijerya'da yaptıkları çalışmada ise yara yeri enfeksiyonlarından en sık izole ettikleri bakterileri sırasıyla P.aeruginosa, E.coli ve Klebsiella pneumoniae olarak bildirmişlerdir. Gram negatif bakterilerin genel olarak antiseptiklere karşı daha dirençli olması ve antibiyotik direnç mekanizmalarının giderek yaygınlaşması nedeniyle gram pozitiflerden daha sık etken olarak karşımıza çıktığı düşünülmüştür.

Gram pozitif bakterilerden stafilokoklar ve enterokoklar yara yeri enfeksiyonlarının önemli etkenleri olarak görülmektedirler. Bunların içinde ise enfeksiyon kaynağı olarak karşımıza en sık S.aureus çıkmaktadır ${ }^{(1,4,6,9,23,27,28)}$. Ülkemizde yapılan çalışmalarda bu suşlarda genellikle vankomisin, teikoplanin ve linezolid direncine rastlanmamaktadır ${ }^{(2,4,23)}$. Davarcı ve ark.'nın ${ }^{(9)}$ 2014-2016 yıllarını kapsayan çalışmalarında S.aureus'ta bu antibiyotiklere direnç görülmezken, enterokoklarda \% 10 vankomisin ve \% 4 linezolid direncine rastlanmıştır. İtalya'da yapılan bir çalışmada yine S.aureus suşlarında vankomisin, teikoplanin, linezolid direncine rastlanmamış; KNS suşlarında ise vankomisin ve linezolid direnci görülmemiş ve \% 28,6 oranında teikoplanin direnci saptanmıştır(6). Malezya'da yapılan bir çalışmada da stafilokoklarda vankomisin direncine rastlanmazken; enterokoklarda \% 1,2 oranında linezolid direnci görülmüş, vankomisin direnci saptanmamıştır(28). Çalışmamızda ise yara örneklerinde üreyen stafilokok ve enterokok suşlarında vankomisin, teikoplanin ve linezolid direnci görülmemiştir. Metisilin direncinin giderek arttığı stafilokoklar düşünüldüğünde, yüksek olan glikopeptid duyarlılığının devamlılığının sağlanması için bu ajanların kısıtlı bildirimi ve kısıtlı kullanımı önem arz etmektedir.

Ampirik tedavide kullanılabilecek antibiyotiklerin direnç oranlarının \% 20'nin altında olması gerekliliği düşünüldüğünde çalışmamızda KNS ve enterokok suşlarında ampirik tedaviye uygun antibiyotiğin olmadığı, S.aureus suşlarında ise TMP-SXT (\% 11), fusidik asit (\% 14), gentamisin (\% 17) ve klindamisin (\% 20) dışındaki antibiyotiklere karşı direnç oranlarının yüksek olduğu görülmüştür. Stafilokoklarda en yüksek metisilin direnci ise KNS suşlarında (\% 61) bulunmuş, S.aureus suşlarından (\% 36) çok daha yüksek olduğu gözlenmiştir. Bu oranları Gündem ve ark. \% 33,3 ve \% 21,7; Avcıoğlu ve ark. \% 58,8 ve \% 16,7 olarak bulmuşken Turhanoğlu ve ark. çalışmamızla benzer şekilde $\% 71,1$ ve $\% 35,8$; Bessa ve ark. $\% 85,7$ ve $\% 21,8$ olarak saptamışlardır ${ }^{(4,6,15,23)}$. TMP-SXT direncinin (\% 11) bu suşlarda ülkemizde yapılan diğer çalışmalarla benzer şekilde oldukça düşük olduğu, eritromisin (\% 34) ve siprofloksasin (\% 24) direncinin ise çalışmamızda çok daha yüksek olduğu bulunmuştur ${ }^{(4,9,23)}$. Saptadığımız yüksek makrolid ve kinolon dirençleri, metisilin dirençli stafilokokların ampirik tedavisinde bu antibiyotik gruplarının uygun olmadığını, TMP-SXT kullanımının ise uygun klinik durumlarda daha etkin olacağını göstermektedir. Yara örneklerinde üreyen enterokokların duyarlılıkları incelendiğinde, Ödemiş ve ark.'nın ${ }^{(20)}$ yaptığı bir çalışmada E.faecium suşları siprofloksasine $\% 86$, yüksek doz gentamisine $\% 67$; E.faecalis suşları ise siprofloksasine $\% 36$, yüksek doz gentamisine $\% 42$, ampisiline $\% 50$ dirençli olarak bulunmuştur. Avcıoğlu ve ark. ${ }^{(4)}$ siprofloksasin ve ampisilin direncini \% 20 olarak bildirmişlerdir. Davarcı ve ark. ${ }^{(9)}$ yüksek doz gentamisin direncini \% 30, ampisilin direncini \% 24 olarak bulmuşlardır. Çalışmamızda ise bu direnç oranları yüksek doz gentamisin için \% 30, ampisilin için \% 31, siprofloksasin için \% 48 olarak saptanmıştır. Avcıoğlu ve ark.'nın(4) 
çalışması ilimize komşu olan Bolu ilinde yapılmış olmasına rağmen direnci daha düşük saptamaları, bölgesel olarak yakın merkezler de bile antibiyotik kullanım politikalarına bağlı olarak direnç oranlarının değişebileceğini düşündürmüştür. Ayrıca enterokok suşlarındaki yüksek siprofloksasin direnci ampirik tedavi için kinolonların kullanımının uygun olmadığını göstermektedir.

Enterobacterales türlerinin antibiyotik direnç oranları incelendiğinde çalışmamıza dahil edilen tüm antibiyotiklere Klebsiella spp. suşlarının diğer bakterilerden daha yüksek oranda ve tüm antibiyotiklere \% 20'nin üzerinde direnç gösterdiğ belirlenmiştir. Avcıoğlu ve ark. ${ }^{(4)}$ ile Cirit ve ark.'nın ${ }^{(8)}$ yapmış olduğu çalışmalarda da benzer şekilde Klebsiella spp. suşlarının diğer bakterilerden daha yüksek oranda direnç gösterdiği belirlenmiştir. Karbapenemler ve aminoglikozidlerin çalışmamızda izole edilen Enterobactericeae üyelerine en etkili antibiyotikler olduğu saptanmıştır. Cirit ve ark.'nın ${ }^{(8)}$ yapmış olduğu çalışmada da benzer sonuçlar bildirilmiştir. Üçüncü kuşak sefalosporin direnci ise enterik bakterilerde giderek artmaktadır. Çalışmamızda E.coli suşlarının sefotaksime \% 57, seftriaksona $\% 55$, seftazidime $\% 54$ oranında direnç saptanmışken Klebsiella spp. suşlarında üç antibiyotiğe de \% 70 oranında direnç olduğu görülmüştür. Davarcıoğlu ve ark. ${ }^{(9)}$ E.coli suşlarının seftazidim direncini \% 60,7, Klebsiella spp. suşlarının seftazidim direncini ise \% 69.7 olarak saptamışlardır. Avcıoğlu ve ark. (4) da E.coli suşlarının seftriakson direncini \% 47,9, seftazidim direncini \% 41,7; K.pneumoniae'nın seftriakson direncini \% 51,5, seftazidim direncini \% 48,5 olarak bildirmişlerdir. Nijerya'da Abdu ve ark.'nın ${ }^{(1)}$ yapmış olduğu çalışmada Gram negatif bakterilerde sefalosporinlere yüksek oranda direnç (sefotaksim \% 91,46, seftriakson \% 91,46, seftazidim \% 87,20) tespit edilmiştir. Bu yüksek direnç Pondei ve ark. ${ }^{(24)}$ tarafından da tespit edilmiştir. Enterobacterales suşlarındaki yüksek sefalosporin direnç oranları genişlemiş spektrumlu beta-laktamaz ve Amp-C beta-laktamaz gibi birçok beta-laktamaz enziminin bakterilerde hızlı şekilde yayıldığını düşündürmektedir.

Nonfermenter bakteriler yara yeri enfeksiyonlarının önemli etkenleridir. Çeşitli çalışmalarda yara yeri enfeksiyonlarında en sık saptanan non fermenter etkenler P.aeruginosa ve Acinetobacter spp. olarak bildirilmektedir ${ }^{(15)}$. Turhanoğlu ve ark. ${ }^{(23)}$ yaptıkları çalışmada Pseudomonas suşlarının gentamisine \% 80,9 , sefepime $\% 73,7$, amikasine $\% 71,5$, seftazidime $\%$ 70,9, siprofloksasine \% 66,7, imipeneme \% 59,6 oranında; Acinetobacter suşlarının gentamisine \% 34,8, siprofloksasine \% 16,7, imipeneme \% 13,1 oranında duyarlı olduğunu bildirmişlerdir. Bessa ve ark.(6) Italya'da 217 enfekte yaranın incelendiği çalışmada 46 (\% 17) örnekte P.aeruginosa üremesi tespit etmişler ve bu suşlarda amikasine \% 81,7, meropeneme \% 69,6, gentamisine \% 60,9 oranında duyarlııı saptamışlardır. Bayram ve ark.'nın ${ }^{(5)} 179$ hastanın yanık yarasının incelendiği çalışmalarında da P.aeruginosa suşlarının 13'ünün (\% 43) çoklu ilaca dirençli olduğu, meropenem, amikasin, siprofloksasin ve sefepimin P.aeruginosa'ya karşı en etkili antibiyotikler olduğu; A.baumannii'ye karşı en etkili antibiyotiklerin ise tigesiklin ve kolistin olduğu tespit edilmiştir. Cirit ve ark. ${ }^{(8)}$ çalışmalarında P.aeruginosa suşlarına en etkili antibiyotikleri meropenem ve tobramisin; A.baumannii suşlarına karşı en etkili antibiyotikleri ise tobramisin, kolistin ve tigesiklin olarak belirlemişlerdir. Çalışmamızda P.aeruginosa suşlarında kolistin duyarlılığı en yüksek olmakla birlikte diğer çalışmalarla benzer şekilde aminoglikozid duyarlılıklarının da diğer antibiyotiklerden daha yüksek olduğu ve Pseudomonas spp. suşlarının A.baumannii suşlarından daha düşük direnç oranlarına sahip oldukları tespit edilmiştir. A.baumannii suşlarnda ise kolistin \% 1 direnç oranıyla en duyarlı antibiyotik iken, tigesiklin \% 33 direnç oranıyla ikinci sırada duyarlı olarak tespit edilmiştir. Özellikle A.baumannii suşlarındaki çoklu ilaç direnci kolistin kullanımını yeniden gündeme getirmiştir. Kolistin duyarlııı̆ı çalışmamızda \% 99 gibi yüksek bir oranda bulunmuştur. Kullanımına bağı nefrotoksisite gibi önemli yan etkilerinin olduğu düşünüldüğünde bu 
ajanın duyarlılığının önerilen şekilde sıvı mikrodilüsyon yöntemiyle doğru şekilde tespit edilmesi gerekmektedir.

Yara yeri enfeksiyonlarında Candida türleri nadir etkenler olarak karşımıza çıkmaktadır. Altan ve ark. ${ }^{(2)}$ tüm yara yeri enfeksiyon etkenleri içerisinde \% 11,4, Avcıoğlu ve ark. ${ }^{(4)} \%$ 0,6 oranında Candida spp. üremesi tespit etmişlerdir. Çalışmamızda ise bu oran \% 3 olarak saptanmıştır. Enfeksiyonun bölgesi, akut ya da kronik olması, hastane kaynaklı olması gibi bir çok değişken nedeniyle farklı merkezlerde farklı oranların olabileceği düşünülmüştür.

Yoğun bakım ünitelerinde tedavi gören hastaların yara yeri örneklerinde üreyen, enterokoklar dışındaki etkenlerin, antibiyotiklerin birçoğuna servis ve poliklinik hastalarında saptanan etkenlerden daha dirençli ve polimikrobiyal olduğu görülmüştür. Yoğun bakım ünitesindeki hastaların genellikle daha ileri yaş grubunda olması, eşlik eden kronik hastalıklarının bulunması ve yoğun antibiyotik kullanımının bu direnç yüksekliğinden sorumlu olduğu düşünülmüştür. Yara yeri enfeksiyonlarında Gram negatif ve Gram pozitif birçok bakteri etken olabilmekte ve yüksek antibiyotik direnci saptanmaktadır. Bu nedenle tüm yara yeri enfeksiyonu düşünülen örneklere kültür ve antibiyogram işlemlerinin yapılarak tedavinin düzenlenmesi gerekmektedir.

Etik Kurul Onayı: Yerel invaziv olmayan klinik araştırmalar etik kurulundan onay alınmıştır (07.12.2020 - 2020/253).

Çıkar Çatışması: Yazarlar tarafından herhangi bir çıkar çatışması bildirilmemiştir.

Ethics Committee Approval: Approval was obtained from the local non-invasive clinical trials ethics committee (07.12.2020 - 2020/253).

Conflict of Interest: No conflict of interest was declared by the authors.

\section{KAYNAKLAR}

1. Abdu $A B$, Egbagba J, Fente BG. Identification and antimicrobial susceptibility profile of bacterial pathogens isolated from wound infections in a tertiary hospital, Bayelsa South southern, Nigeria. Trop J Pathol Microbiol. 2019;5(12):966-75.

https://doi.org/10.17511/jopm.2019.i12.01

2. Altan G, Mumcuoğlu i, Hazırolan G, Dülger D, Aksu N. Yara örneklerinden izole edilen mikroorganizmalar ve antimikrobiyallere duyarlılıkları. Turk Hij Den Biyol Derg. 2017;74(4):279-86. https://doi.org/10.5505/TurkHijyen.2017.81598

3. Aşık G, Özoğuz $P$, Tünay $H$, Bulut $A$, Kaçar $S$, Bal A. Yara kültürlerinden izole edilen etkenler ve antibiyotik direnç profilleri. Cerrahi Sanatlar Derg. 2014;7(1):1822.

4. Avcıoğlu F, Behçet M, Karabörk Ş, Kurtoğlı MG. Yara örneklerinden izole edilen mikroorganizmaların antimikrobiyal direnç oranları - üç yıllık değerlendirme. DÜ Sağlık Bil Enst Derg. 2019;9(3):110-14. https://doi.org/10.33631/duzcesbed.538681

5. Bayram Y, Parlak M, Aypak C, Bayram I. Three-year review of bacteriological profile and antibiogram of burn wound isolates in Van, Turkey. Int J Med Sci. 2013;10(1):19-23. https://doi.org/10.7150/ijms.4723

6. Bessa LJ, Fazii P, Di Giulio M, Cellini L. Bacterial isolates from infected wounds and their antibiotic susceptibility pattern: some remarks about wound infection. Int Wound J. 2015;12(1):47-52. https://doi.org/10.1111/iwj.12049

7. Bowler PG, Duerden BI, Armstrong DG. Wound microbiology and associated approaches to wound management. Clin Microbiol Rev. 2001;14(2):244-69. https://doi.org/10.1128/CMR.14.2.244-269.2001

8. Cirit OS, Müderris T, Mızraklı A, Vurupalmaz Y, Barış A. Yara kültürlerinden izole edilen aerop bakteriler ve antibiyotik duyarlılıkları. Türk Mikrobiyol Cem Derg. 2014;44(4):149-57.

9. Davarcı I, Koçoğlu ME, Barlas N, Samastı M. Yara kültürlerinde izole edilen bakterilerin antimikrobiyal duyarlılıkları: üç yıllık değerlendirme. ANKEM Derg. 2018;32(2):53-61. https://doi.org/10.5222/ankem.2018.053

10. Demirel M, Demiralp CÖ, Yormuk E. 2000-2005 yılları arası bası yaraları: klinik deneyimler. Ankara Üni Tıp Fak Mec. 2007;60(2):81-7.

11. Doğan SŞ, Paköz NiE, Aral M. Laboratuvarımıza gönderilen yara yeri örneklerinden izole edilen mikroorganizmalar ve antibiyotiklere direnç durumları. Türk Mikrobiyol Cem Derg. 2010;40(4): 243-9.

12. Dündar D, Özcan SK, Atmaca E. Evde bakım hizmeti verilen hastaların bası yaralarındaki yüzeyel kolonizasyonun mikrobiyolojik incelenmesi. Kocatepe Tip Derg. 2012;13(1):27-32.

13. Espejo E, Andres M, Borrallo R-M, Padilla E, et al. Associated with pressure ulcers: a prospective cohort study. Eur J Clin Microbiol Infect Dis. 2018;37(5):96975.

https://doi.org/10.1007/s10096-018-3216-8

14. Görmeli G, Duman Y, Karakaplan M, et al. Orthopedic Surgical wound infection: microorganisms and resistance figures. J Turgut Ozal Med Cent. 2015;22(1):13-7.

15. Gündem NS, Çikman A. Yara kültürlerinden izole edilen mikroorganizmalar ve antibiyotik duyarlılıkları. ANKEM 
Derg. 2012;26(4):165-70. https://doi.org/10.5222/ankem.2012.165

16. Güriz H, Çiftçi E, Gökdemir R, Aysev D. Ankara Üniversitesi Tıp Fakültesi Cebeci Hastanesindeki yara kültürlerinin değerlendirilmesi. Ankara Üni Tıp Fak Mec. 2001; 54(3): 231-5.

17. Okeke IN, Laxminarayan R, Bhutta ZA, Duse AG, Jenkins P, Brien TF, Pablos-Mendez A, Klugman KP. Antimicrobial resistance in developing countries. Part I: recent trends and current status. Lancet Infect Dis. 2005;5(8):48193.

https://doi.org/10.1016/S1473-3099(05)70189-4

18. Owens $C D$, Stoessel K. Surgical site infections: epidemiology, microbiology and prevention. J Hosp Infect. 2008;70(Suppl 2):3-10. https://doi.org/10.1016/S0195-6701(08)60017-1

19. Özmen E, Geyik MF, Uluğ M, Çelen MK, Hoşoğlu S, Ayaz C. Yatan hastalardan izole edilen gram negatif bakteriler ve antibiyotik dirençlerinin değerlendirilmesi. Düzce Tıp Fak Derg. 2010;12(3):32-9.

20. Pondei K, Fente BG, Oladapo O. Current microbial isolates from wound swabs, their culture and sensitivity pattern at the Niger delta university teaching hospital, Okolobiri, Nigeria. Trop Med Health. 2013;41(2):49-53. https://doi.org/10.2149/tmh.2012-14

21. Segre JA. Epidermal barrier formation and recovery in skin disorders. J Clin Invest. 2006; 116(5): 1150-8. https://doi.org/10.1172/JCl28521

22. The European Committee on Antimicrobial Susceptibility Testing - EUCAST. MIC and zone diameter distributions and ECOFFs, V.9.0 valid from 2019-01-01.
23. Turhanoğlu NM, Koyuncu E, Bayındır Bilman F. Microorganisms and antibiotic resistances isolated from wound cultures 2010-2015. Turk Hij Den Biyol Derg. 2018;75(2):183-94. https://doi.org/10.5505/TurkHijyen.2018.56338

24. Yıldırım AM, Çarkçı, HA, Yılmaz M, Toraman ZA. Yanık ve yara örneklerinden izole edilen mikroorganizma türlerinin belirlenmesi ve antimikrobiyal duyarlılıklarının araştırılması. Kocatepe Tıp Derg. 2019;20(1):26-32.

https://doi.org/10.18229/kocatepetip.532122

25. Yurtsever SG, Kurultay N, Çeken N, ve ark. Yara yeri örneklerinden izole edilen mikroorganizmalar ve antibiyotik duyarlılıklarının değerlendirilmesi. ANKEM Derg. 2009;23(1):34-8.

26. Zafar A, Anwar N, Ejaz H. Bacteriology of infected wounds - a study conducted at Children Hospital Lahore. Biomedica. 2007;23:8(A):1-4.

27. Zdravkovska M, Serafimovska T, Ribarska JT, Dimitrova M, Zivkova S, Georgijev A, Sadikarijo I, Balkanov T, Darkovska-Serafimovska M. Commonly isolated pathogens from postoperative wounds and antibiotic susceptibility testing at a tertiary care hospital in Stip, North Macedonia. IOSR J Pharm. Volume 10, Issue 2 Series. I (February 2020), PP. 46-52

28. Wong SY, Manikam R, Muniandy S. Prevalence and antibiotic susceptibility of bacteria from acute and chronic wounds in Malaysian subjects. J Infect Dev Ctries. 2015;9(9):936-44. https://doi.org/10.3855/jidc.5882 